\title{
Review
}

\section{Textual conspiracies: Walter Benjamin, idolatry, and political theory}

\author{
James R. Martel \\ University of Michigan Press, Ann Arbor, 2011, xii+305pp., \\ ISBN: 978-0472117727
}

Contemporary Political Theory (2014) 13, e5-e8. doi:10.1057/cpt.2013.38

Amidst recent strands of thought that shift the primary loci of inquiry away from the
linguistic turn towards a renewed negotiation with materiality, a crucial question arises: what should one do with texts, seemingly torn between the world of signification and thinghood? James Martel's Textual Conspiracies: Walter Benjamin, Idolatry, and Political Theory, while ostensibly a compelling piece of Benjamin scholarship, provides a provocative answer. Martel uncovers in Benjamin a conspiracy taking place 'in texts and/or with objects' rather than intentionality (p. 18). Rather than treating texts as bearers of meaning, Martel emphasizes their materiality, and their ability to open political space beyond their creators' intents. He advances a novel account of the politics of texts, one in which their material existence facilitates the creation of communities in divergent times and locations. Thus Textual Conspiracies provides interesting resources not only for students of Benjamin, but for those engaged in debates over the politics of 'New Materialism'.

Martel reads Benjamin as conspiring with language against human intentionality, which has become implicated in the practices of commodity fetishism that constitute the 'phantasmagoria' of late capitalism (p. 9). Representation not only distorts reality, but the desire for an unmediated access to the reality sustains the ideological hold of signs and symbols. Instead of purifying representation, Martel's Benjamin locates within the materiality of texts an independent power to outlast and act against the author's intentions (p. 10). This materiality is not and cannot be a Ding-an-sich 'fully free from delusion and the misreading of signs', but can help cause 'our delusions [to] become legible to us as such' (p. 13). Misrecognitions, misinterpretations and aporias expose the limits and remainders of the phantasmagoria, animating an 'alien hope' in future projects of political emancipation, even if such hope is 'not for us' (p. 20).

Martel's book employs the conspiratorial method itself, placing Benjamin in a constellation of a variety of thinkers and writers. Beginning with Benjamin's

(C) 2014 Macmillan Publishers Ltd. 1470-8914 Contemporary Political Theory Vol. 13, 4, e5-e8 www.palgrave-journals.com/cpt/ 
attraction to the failed Bohemian conspiracies (p. 28), which provide a lesson on the lasting powers of texts (p. 34), Martel emphasizes the productive power of failure. For Benjamin, Baudelaire's failed conspiracies create moments of misrecognition that expose the limits of representation (p. 36) and create opportunities for later conspirators to reconfigure, re-signify and re-constellate texts for other purposes (p. 55). Kafka's parables that fail to convey meaning (p. 69), his perpetually unrecognized messiah (p. 71) and Machiavelli's publicity of secret counsel in The Prince (p. 93) provide additional examples. These conspiracies do not reveal hidden truths, but create space for distant conspirators to engage these projects in divergent contexts. Intentionally reading texts out of context produces new meanings and interpretations that challenge the totality and certainty of meaning offered by the phantasmagoria.

Martel does not provide an explicit account of these conspiracies' political subversion; such an account would violate his own commitment to foregoing intentionality as the privileged political site. However, he does provide a series of novel readings by engaging three pairings of literary writers and political thinkers that illuminate the ability of texts to build conspiracies across time and space. He engages Alexis de Tocqueville and Edgar Allen Poe on the possibility of representing the phantasmagoria, Hannah Arendt and Federico Garcia Lorca on the role of human agency in conspiracies, and Frantz Fanon and Assia Djebar on potential positive steps to be taken (p. 110). In each pair, Martel mobilizes fugitive resources within the texts that disrupt settled readings. For example, he excavates Arendt's hesitation concerning the politics of unmediated appearance (p. 157) and distrust of human willing (p. 161). Instead of apolitical pessimism or an heroic account of action, Martel's reading highlights the dangers of believing that representational distortions are overcome or that political struggles are complete.

What emerges is an account of politics that eschews "perfect truth or redemption ... but it does subvert and resist what would otherwise be a nearly perfect substitute for reality, the phantasmagoria' (p. 232). Martel's emphasis on a text's materiality that prevents it from being fully captured by phantasmagoric representation shares an affinity with thinkers broadly described as 'New Materialists', of which I take Jane Bennett's Vibrant Matter to be exemplary but not exhaustive.

In this constellation, Martel's text better illuminates the political potential of materiality, which exceeds or evades human intentionality. Bennett characterizes both materiality's recalcitrance to human intentions and non-human assemblages' independent political effects as 'thing-power' (Bennett, 2010, pp. 2-6). Similarly, Martel focuses on how a text's materiality allows it to act 'as a kind of independent agent, an ally not a tool' (p. 34). Texts therefore can have independent political effects beyond the original authorial intentions, but are also recalcitrant, never simply props for political projects. As Martel notes, 'the individuals and communities that are formed in the face of some central referent (God, the state, the green flags of Islam, etc.) have an existence that is distinct from that referent; 
they can survive and even flourish when such a referent is decentered. But they can do so only if they give up on "hope," on the assurances of delivery by the referent itself' (p. 148). Texts and things, being irreducible to representation, can provide anchors for different potential readings and conspiracies. Yet harnessing this excessive power requires abandoning faith in inert matter or true meaning, and clinging to these unpredictable objects without knowledge of their final destinations.

This broader materialist constellation questions the ontological scope of Martel's claims: is this excess beyond representation a property only of texts or of matter as such? His language entertains possibilities of the latter, frequently pointing to alliances with things from Poe's 'water-cask' (p. 144) to Djebar's 'green flags of Islam' (p. 218). Both serve as potential allies in constituting political communities within rather than beyond regimes of representation. Yet, for both their materiality is within a text. Bringing Martel's conspiratorial method into conversation with 'New Materialism' expands the number of potential conspirators to broader assemblages of things affecting and creating politics beyond their symbolic value. This more expansive constellation of non-human conspirators challenges Martel to follow his critique of human intentionality to its culmination: recognizing the political potency of materiality itself and not just texts crafted by humans.

Is the diffusion of human agency through conspiracies with material texts or assemblages with vibrant things merely a Pyrrhic victory? On the one hand, by replacing hubristic utopian thought with the alien hope of conspiracy, Martel warns of the dangers inherent in attempting to purify the world of representation. Similarly, by displacing human agency, in favor of alliances with materiality, Martel maintains that our political intentions are truly self-executing. On the other hand, however, by denying any positive politics to intentionality, only granting the hope for some future conspirator, Martel's project can be read as political quietism. When faced with oppression, must the Left abandon political claim-making and cling to the texts and objects floating by?

Thus the central challenge of Martel's book is finding the remaining space for political action without the false hope of escaping the phantasmagoria. Martel's conspiracies are not rejections of agency, but recognitions that the texts, things and communities that surround us are not merely fetishistic commodities, but political allies. The lack of a definitive view of political emancipation may paradoxically be the book's strength. Rather than giving the Left a blueprint for escaping capitalist domination, it provides resources for undermining the phantasmagoria's claims to certainty. Martel aids the broader materialist project by demonstrating the power of texts, especially 'failed' texts, to expose the inadequacies, misrecognitions and remainders inherent in all representation. Emerging from Textual Conspiracies is an account of political agency as necessarily part of an assemblage of texts, things and fellow conspirators diffused through time and space. 


\section{Reference}

Bennett, J. (2010) Vibrant Matter: A Political Ecology of Things. Durham, NC: Duke University Press.

M. Christopher Sardo

Northwestern University, Evanston, IL 60208, USA

e8 C 2014 Macmillan Publishers Ltd. 1470-8914 Contemporary Political Theory Vol. 13, 4, e5-e8 